\title{
Dwa listy Kazimierza Ajdukiewicza do Romana Witolda Ingardena z 1928 roku
}

\author{
List Kazimierza Ajdukiewicza \\ do Romana Witolda Ingardena z 3 stycznia 1928 roku
}

Warszawa, 3 stycznia 1928 roku

Mój Kochany!

List Twój pisany w Marburgu, a wysłany z Paryża, otrzymałem przed chwila; odpowiadam nań natychmiast bez długiego namysłu i bez stylizowania - na gorąco. Nie jest przyjemną rola oskarżonego, a mimo to przyjemnie jest mi, że czując do mnie w sprawach tak delikatnych żal, piszesz do mnie otwarcie, co Cię pewno - ze względu na delikatność materii - musiało przyprawić ono!, co Ci pewnie nie było przyjemne [sic!].

Postaram się przedstawić obiektywnie moją rolę w staraniach o moje powołanie. Otóż ja byłem uchwałą Rady Wydziałowej powołującej mnie - przepraszam! - Komisji Filozoficznej powołującej mnie najzupełniej zaskoczony. Otrzymałem pewnej nocy telegram od dziekana Bulandy i od Twardowskiego, zawiadamiający mnie o tej uchwale i domagający się, bym w ciągu 48 godzin dał odpowiedź, czy powołanie przyjąłbym. O tym wszystkim nic przedtem nie wiedziałem. Odpisałem po krótkim, ale ciężkim namyśle, że o ile względy materialne mi na to pozwola, powołanie przyjmę. Nie przychodziło mi nawet wtedy na 
myśl zwracać się z tą sprawą do Ciebie. Wtedy zapewne przez egoizm, który to sposób postępowania dziś jednak tak bym usprawiedliwiał. Nie kryłem tego nigdy, że rozstanie się ze Lwowem przychodzi mi ciężko, nawet publicznie powiedziałem - w Twojej obecności - że gdy się tylko da wrócić do Lwowa, to wrócę.

Pracując przez szereg lat, jako docent we Lwowie, proponowany tamże - bezskutecznie - na katedrę, sądzę, że należę do tych, którzy o ile chodzi o względy pozanaukowe - mają prawo myśleć o powołaniu na równi z obecnymi docentami. Co do kwalifikacji naukowych moich i porównywania ich z Twoimi - trudno mi coś powiedzieć, na serio nie wiem, który z nas [jest] więcej wart. Przypuszczam, że każdy z nas lepszy [jest] na swoim podwórku, w swojej specjalności. Sądzę zaś - może to stronnicze - ważniejszą jest rzeczą uczyć ludzi po mojemu niż po Twojemu. I nie dziwię się sobie i nie mam sobie tego nawet za złe, że nie powiedziałem w odpowiedzi na zapytanie dziekana lwowskiego „Może lepiej by było, gdybyście powołali Ingardena?”. Kiedy inni, mogąc wybierać między mną a kimś innym, wybrali mnie, a ja nie uważam siebie za zdecydowanie gorszego, czyż miałbym się usuwać i proponować drugiego? Ale może, powiadasz, trzeba było ważyć, komu z nas dwóch to większą wartość przyniesie. Powiadasz, że dla mnie to tylko przyjemność, dla Ciebie możność pracy naukowej. Mój Drogi, czy tak na pewno możesz wiedzieć, czy dla mnie to przeniesienie do Lwowa nie jest rzeczą bardziej potrzebną i cenna, jak dla Ciebie powołanie na katedrę. Czy na przykład nie sądzisz, że mogłoby tak być, że dla mnie egzystencja $\mathrm{w}$ Warszawie jest z jakichś względów równie przykra, jak dla Ciebie Twoje obecne warunki we Lwowie?

Może to wszystko, co wyżej napisałem, nie dotyczy spraw przez Ciebie wyraźnie wymienionych, dotyczy jednak - przypominam - spraw, o których pomyślałeś, a o które mnie chodzi w ustępie Twego listu, w którym piszesz, że należało mieć do Ciebie zaufanie w obiektywność Twego sądu i zapytać Cię, czy moja obecność w Uniwersytecie Lwowskim jest potrzebna. Miałem zresztą już dawniej dowody tego, że tak myślisz, iż jest potrzebna, a nie miałem powodu sądzić, że swój pogląd w Tej sprawie zmieniłeś. Na koniec, czyż istotnie byłoby moim obowiązkiem pytać się Ciebie, czy uważasz mnie za potrzebnego we Lwowie? Tyle dla usprawiedliwienia mojego „nieliczenia się" z Tobą przy mojej odpowiedzi, udzielonej dziekanowi na jego pytanie, czy przyjąłbym powołanie do Lwowa.

Telegram ów i uchwała Rady Wydziałowej i Senatu powołująca mnie do Lwowa zapadły, jeśli się nie mylę, w listopadzie 1926. Przed uchwałą Rady Wydziałowej nie miałem - jak widzisz z krótkości terminu mi wyznaczonego - nawet fizycznej możności porozumienia się z kimkolwiek. Z końcem grudnia tegoż roku - miałem wtedy odczyt o pytaniach - byłem we Lwowie i wtedy przy najbliższym widzeniu się 
z Tobą o moim powołaniu do Lwowa Ci zakomunikowałem. Nie pisałem Ci tego wcześniej, gdyż ja w ogóle nie jestem - ani w korespondencji prywatnej, ani w innych sprawach - piśmienny. Nie przypuszczałem zreszta, żebyś o tej sprawie nie wiedział.

Zatem: żadnej polityki względem Ciebie nie uprawiałem. O mającym nastąpić powołaniu mnie dowiedziałem się w chwili, gdy sprawa ta przeszła już przez Komisję i w przeddzień prawie uchwały Wydziału. Nigdy bym nie przypuszczał, żebyś Ty na moją niekorzyść choćby palcem ruszył i nie uważałbym za celowe tajenie przed Tobą tej sprawy. Na miłość boska, znasz mnie przecież i wiesz, że jestem przeciwieństwem człowieka uprawiającego „politykę"! W wypadku, gdy na stanowisko, którego pragnę, z dwóch ludzi mnie wybierają (bez mojego współudziału), zrzekłbym się tego wyboru, gdybym uważał: bądź, że się od drugiego znacznie mniej na to stanowisko nadaję, bądź, że dla tamtego jest to sprawą niesłychanie ważną, a dla mnie stosunkowo błahą. W wypadku, o którym mowa, żadna $\mathrm{z}$ tych ewentualności nie zachodziła.

Na koniec sprawa mojego odczytu o pytaniu. Przejrzałem Twą książkę dzisiaj, aby stwierdzić, czy istotnie między moim odczytem a odnośnym ustępem zachodzą punkty wspólne. Otóż zdaje mi się, że zachodzą dwa takie. Pierwszy dotyczy tego, że wedle Ciebie w każdym pytaniu jest "die Unbekannte", wedle mnie w każdym pytaniu występuje zmienna. Ty mówisz o „richtige Frage”, ja, mówiąc o błędach pytania, wspomniałem o pytaniach nietrafnie postawionych, jednak w sensie nieco odmiennym od tego, w którym Ty tego zwrotu używasz. Zdaje mi się, że innych punktów wspólnych nie ma. Otóż, co do kwestii autorstwa, to miałem jeszcze w 1923 roku odczyt o pytaniu "co to jest", streszczony w Ruchu Filozoficznym, którego pod ręką nie mam, w którym to odczycie mówiłem już o finezji zdaniowej wyznaczonej przez pytanie; nazywałem ją datum quaestionis. Funkcja zdaniowa zawiera zmienną, więc ta moja koncepcja „niewiadomej pytania” od Ciebie nie pochodzi. Dowodów na oryginalność mojej koncepcji pytań, trafnie postawionych dowodów nie posiadam. Odczyt ten wygłosiłem naprzód w Warszawie i tu pamiętam, że mówiłem wyraźnie o różnych autorach zajmujących się sprawą pytania i między nimi wymieniłem też i Ciebie. Czy we Lwowie to uczyniłem, tego nie pamiętam. Tyle, co do strony faktycznej. O jakimś panu stale przebywającym poza Lwowem, który by mówił o nowości moich poglądów, nic nie wiem.

Proszę Cię obecnie o przyjęcie mojego najsolenniejszego zapewnienia, że ów fakt niewymienienia Twojego nazwiska w tym odczycie nie był $\mathrm{w}$ żadnym razie zamierzony, a w żadnym razie nie miał na celu uniknięcia twego nazwiska, aby broń Boże ktoś sobie o Twojej egzystencji nie przypomniał. 
A więc raz jeszcze. Nie uprawiałem wobec Ciebie żadnej polityki. Wszystko mnie upoważniało do wierzenia, że nie uczynisz żadnego kroku na moją niekorzyść, wierzyłem bowiem szczerze w Twoją życzliwość. Nie przypuszczałem nawet, żebyś nie wiedział o dokonanych w celu powołania mnie krokach. Przed wszczęciem całej akcji sam o niej nie wiedziałem. Nigdy nie szedłem do swoich celów drogą nielojalną w stosunku do osób, które miały prawo wierzyć w moją przyjaźń. Przykro mi o tym wspominać, ale przecież bez mojego przyczynienia się nie miałbyś mianowania we Lwowie, a tym samym możności trwałej egzystencji w tym mieście. Wszakże gdybym się obawiał Twojej konkurencji i czynił $\mathrm{w}$ tym kierunku, by ją usunąć, jakieś kroki, byłbym tego nie czynił.

Przykro mi, przykro bardzo, że cały mój stosunek do Ciebie nie dał Ci dostatecznych podstaw do tego, by Cię przekonać, że wszystkie Twoje podejrzenia są pozbawione uzasadnienia.

Na koniec, ani moje przybycie do Lwowa nie jest pewne, ani też objęcie katedry przeze mnie nie czyni mniej realnymi widoków na katedrę dla Ciebie.

Proszę Cię teraz bardzo serdecznie i nalegam, żebyś mi jak najprędzej odpisał szczerze i otwarcie, czy moje wyjaśnienia wystarczają Ci dla usunięcia wszelkich nieporozumień między nami, a gdybyś widział jeszcze punkty niejasne, proszę Cię, daj mi znać. Na zupełnie czystym horyzoncie między nami zależy mi bardzo.

Teraz kończę zapewnieniem zachowanej dalej szczerej przyjaźni.

Twój Kazik

\section{List Kazimierza Ajdukiewicza do Romana Witolda Ingardena z 10 marca 1928 roku}

Warszawa, 10 marca 1928 roku

Kochany Romku!

Nie mogłem się wybrać z długim listem do Ciebie, więc aby przecież napisać, piszę ten krótki. Mój kochany Romku - nie gniewam się i gniewałem wcale, i mam nadzieję, że wszelkie lody między nami pękną, gdy się Twarzą w Twarz zobaczymy. A mam nadzieję, że nastąpi to już niedługo, gdyż najprawdopodobniej od Wielkanocy będę we Lwowie na stałe. Za trzy Twoje listy, które dotąd pozostawiłem bez odpowiedzi, Ci najserdeczniej dziękuję, jak również za życzenia imieninowe. Zdaje mi się, że przegapiłem Twoje imieniny, które lokowałem uprzednio 
w sierpniu, a które, zdaje się, obchodzisz w lutym. Toteż, jeśli się nie gniewasz na zbyt późny termin, przyjmij z mojej strony najserdeczniejsze życzenia i wyrazy szczerej radości, że będziemy współżyli i współpracowali razem. W ostatnich czasach, $\mathrm{z}$ powodu różnych zmartwień, tak zostałem wytrącony z równowagi, że na myślenie, poza zadanym pensum uniwersyteckim, nie zostało mi ani spokoju, ani głowy. Cieszę się dla Ciebie, że udało Ci się nowe dzieło wykończyć i bardzo bym chciał, żeby Ci zjednało uznanie.

A teraz przyjmij najserdeczniejsze pozdrowienia od szczerze Ci oddanego Kazika 